\title{
教材活用の仕方や指導行動が学習成果に及ぼす影響について： 特に開脚跳びのできない児童に対する学習指導を中心に
}

The influence of the usage of teaching materials and teachers' teaching behavior toward students' achievement: Especially to students who fail to jump vault horse.

\author{
南島 永衣子：Eiko MINAMISHIMA ${ }^{\prime}$ \\ 高 橋 健 夫：Takeo TAKAHASHI ${ }^{2}$
}

1 愛媛女子短期大学：Ehime Women's College

421 Ibuki, Uwajima, Ehime, 798-0025

2 日本体育体育大学: Nippon Sport Science University

7-1-1 Fukasawa, Setagaya, Tokyo, 158-8508

\begin{abstract}
In this study, by using materials that are said to be effective for skill acquisition of the straddle vault skill of long-box, the collection of cases of instruction-words toward students' various failures which occur when students learn straddle vault skill are made by three primary school teachers who took the classes and by the researcher. Referring to the teaching material and the collection of cases of instruction-words, those three teachers planed an original unit (6hours) of long-box activity and practiced. Therefore the purpose of this paper is to analyze the lessons for students who fail to jump long-box from the perspectives of an order of lesson plan, arrangements and usage of lower teaching materials and effects of teachers' teaching behavior toward students.

As a result, to design appropriate lesson plans for students, to give appropriate teaching materials according to each student' $s$ ability and to give appropriate tasks and verbal feedbacks (teachers' behavior) are necessary to guarantee students the basic straddle vault skill of long-box.
\end{abstract}

\section{I. 緒 言}

文部科学省の中央教育審議会の教育課程部会の 「審議経過報告 (18 年2月13日)」は、学習指導要 領の改訂に向けて「学力重視」の基本方針を打ち 出した (文部科学省, 2006)。現行の学習指導要領 でも基礎的・基本的な知識・技能を徹底して身に つけさせ、自ら考える力を育成することを极らい としてきたが、各種の調査結果からそのねらいが
十分達成できていない状況がみられる。そのこと から、改めて「確かな学力の育成」をテーマに揭 げ、基礎的・基本的な知識・技能の育成（習得型 の教育) と自ら学び自ら考える力の育成 (探求型 の教育) の両面を尊重していく方針を明らかにし ている。「健やかな体を育む教育のあり方」専門部 会の「審議経過報告（17 年9月29日）」でも、体 育の説明責任に応えるため、「身体能力」、「知識、 
思考・判断」「態度」の各領域に関わった到達目 標をできるだけ具体的に提示する方針で作業が進 められている(文部科学省, 2005)。これまでの体 育科では、運動の楽しさ経験が強調され、プレイ のライフスタイルに対応して、子どもたちの自主 的・自発的学習が推奨されてきたが(文部科学省, 2005a)、そのような方向のなかで、基礎的・基本 的な能力の育成という課題が明確に意図されてき たとはいえず、今後はこれまでの反省をふまえ て、各運動領域での最低限の技能を保障するため の指導のあり方が強く求められていくものと予想 される。

なお、これまでも運動技能を保障することに関 心がなかったわけではなく、技能保障に向けた教 材開発や指導法の研究が数多く行われてきた。と りわけ、跳び箱運動の開脚跳びについては多くの 関心を集め、多様な下位教材が開発されるととも に、それらに関連した指導技術が提案されてきた (向山, 1981 ; 進藤, 1981 ; 小林, 1981 ; 小久保, 1981 ; 高橋, 1987 ほか)。総じて、開脚跳びの場 合、「腕を支点とした体重移動及び体の切り返し」 や「踏み切りから着手までの体の投げ出し」と いった基礎的な感覚やわずかなコツが身につけ ば、誰もが容易に習得できると考えられ、それら の能力習得のための下位教材が開発されてきた (金子, 1987 ; 高橋, 1991 ほか)。

しかしながら、実際の体育授業場面を想定する と、このような下位教材を適用するだけでただち に開脚跳びができるようになるわけではない（岩 田，1994）。授業場面では、教材解釈を含め、実践 的な指導力が重要になってくるからである。その ため、運動学習時間確保のためのマネジメント能 力、また、下位教材の配置 - 配列として授業の計 画や立案能力、そして、授業中における教師の指 導行動が重要であると考えられる。これらの教師 の考え方や指導力の違いが学習成果に強く影響す るものと予想できる。

そこで本研究では、授業分析を通して、マネジ メント能力、授業計画、教材提供の仕方、さらに、 下位教材に関わる指導行動から、教師の指導力の 重要性を確かめることを目的とした。

なお、本研究では、開脚跳びの達成に有効だと 考えられている「下位教材群」や、「つまずきに対
応した指導言葉集」を 3 名の小学校教師に資料と して提供し、それらが実際の体育授業においてど のように計画・実行され、その結果、どのような 学習成果をもたらすのか観察・分析することにし た。具体的には、(1)開脚跳びを中心とした運動学 習場面の時間的確保、(2)指導計画において、提供 された下位教材の配置・配列の仕方、(3)授業場面 における教師の指導行動（学び方の指導、教材の 提示、運動課題の提示、補助、言語的フィードバッ ク）の3点である。これら教師の計画や指導行動 が、開脚跳び越しのできない児童の学習成果にどの ように影響したのかを分析・検討することにした。 その際、研究者サイドから「下位教材群」(表1) や「つまずきに対応した指導言葉集」(表2)を資 料として提供したが、それらを授業計画や授業実 践にどのように適用すべきかは一切介入せず、担 当教師の自由裁量とした。

\section{II. 研究方法 \\ 1. 対象と授業実践の実施時期 $<\mathrm{A}$ 単元 $>$}

茨城県 $H$ 小学校 2 年生 1 クラスを対象に、K教 諭が「跳び箱遊び(基本の運動)」の授業を行った。 実施時期は平成 16 年 5 月中旬から 6 月上旬の 6 授 業時間。

$<B$ 単元 $>$

埼玉県 $\mathrm{Z}$ 小学校 3 年生 1 クラスを対象に、W 教 諭が「跳び箱遊び(基本の運動)」の授業を行った。 実施時期は平成 16 年 6 月上旬から中旬の 6 授業時 間。

\section{$<\mathrm{C}$ 単元 $>$}

さいたま市 N小学校 4 年生 1 クラスを対象に、Y 教諭が「跳び箱運動」の授業を行った。実施時期 は平成 16 年 9 月中旬から下旬の 6 授業時間。

なお、これらの授業の撮影及び分析は、3名の 担当教師をはじめ、保護者ならびに学校側の了承 を得て行われた。

\section{2. 下位教材の提供}

単元計画と実践に先立ち、開脚跳びの基礎的感 覚を直接的・間接的に習得させることをねらっ て、高橋（1992，1998）や、松井（1983）、上條 (1992)、藤井 $(1992,1997)$ 、松本（1999）、渡辺 
（2000）などが開発した下位教材群を教師に提供 した（表 1)。

\section{3. 指導言葉の提供}

開脚跳び及びその下位教材に関わって生じると 予想される児童の「つまずきに対応した指導言葉 の事例集」を担当教師に提供した（表2）。3名の 教師はこれらの資料を活用して、それぞれ自分の 考えに基づいて単元計画（6時間）を立て、自由 に授業を実践した。

\section{4. 授業の観察と分析} <授業場面の期間記録の分析>

運動学習場面の時間的確保が授業成果を高める うえで重要な意味をもつことが明らかにされてい ることから (高橋, 2003)、体育授業場面をインス トラクション場面、マネジメント場面、認知学習 場面、運動学習場面の 4 場面に区分して観察記録 し、それぞれの配当時間量を計測した。 <活用された下位教材の分析>

資料として提供された下位教材が単元計画にど

表 1. 提供した下位教材群

\begin{tabular}{|c|c|}
\hline $\begin{array}{l}\text { 技術的な } \\
\text { 学習内容 }\end{array}$ & 下位教材 \\
\hline \multirow[b]{2}{*}{ 踏み切り感覚 } & スキップ \\
\hline & $\begin{array}{l}\text { ケンパー跳び(ケン・パー、ケン・パー } \\
\text { ケン・ケン・パーのリズムで跳ぶ) }\end{array}$ \\
\hline \multirow{3}{*}{ 体の投げ出し } & 跳び箱や簡易跳び箱への跳びのり \\
\hline & 空中遊泳（ウルトラマン跳び） \\
\hline & 連結跳び箱（長馬）での跳びのり \\
\hline \multirow{2}{*}{$\begin{array}{l}\text { 足一手一足の順次性 } \\
\text { 於こび体の切り返し }\end{array}$} & うさぎ跳び \\
\hline & うさぎ跳びのライン越し \\
\hline \multirow{6}{*}{ 腕支持感覚 } & 手足走り \\
\hline & 色々な動物歩き \\
\hline & アザラシ \\
\hline & カエルの足打ち \\
\hline & 手押し車 \\
\hline & カエル倒立 \\
\hline \multirow{5}{*}{$\begin{array}{l}\text { 腕を支点とし } \\
\text { た体重移動と } \\
\text { 切返し }\end{array}$} & 馬跳び \\
\hline & うさぎ跳び \\
\hline & 改脚座からの支持跳び出し \\
\hline & $\begin{array}{l}\text { 連結跳び箱 (長馬) での開脚座腕支 } \\
\text { 持移動 }\end{array}$ \\
\hline & $\begin{array}{l}\text { 簡易跳び箱(ビールビンケース、丸イ } \\
\text { ス)での跳び越し }\end{array}$ \\
\hline
\end{tabular}

のように反映されたか、また、実際の授業場面で どのような下位教材が活用されたのかを観察・分 析した (なお、単元計画については紙数の関係で 省略した)。

\section{＜活用された指導言葉の分析＞}

開脚跳び及びその下位教材の学習に対して、特 に技能下位児童へ与えられた教師の言語的フィー ドバック（以下、フィードバックとする）を組織 的観察法（高橋ほか、1991a）によって記録・分析 するとともに、状況関連的に教師の言語を逐語記 録し、それらの言語が児童の技能改善や向上につ ながったかどうかを検討した。

なお、教師の言語的フィードバックの適否につ いては、表2の各技術的課題と照らし合わせ、同 じもしくは、同じような内容のフィードバックの み回数をカウントし、それ以外のフィードバック についてはノーカウントとした。

\section{〈技能テストと下位児の学習行動の分析＞}

単元前後において、文部科学省規定の「3 段の 跳び箱 (長さ $78 \mathrm{~cm}$, 高さ $50 \mathrm{~cm}$, 幅 $35 \mathrm{~cm}$ )」で児 童の技能レベルを評価した(表3)。技能レベルは、 助走のある状態で両足踏切から両手による着手、 さらに両足着地までの動きが見られるものを「開 脚跳び」ができるとし、助走が無く、跳び箱に着 手した状態からの跳び越しもしくは、助走はある が片足による踏切や着手、着地によって跳べたも のはすべて「開脚跳び越し」ができたとした。こ の技能レベルにおいて、開脚跳び越しのできな かった児童の中からそれぞれ3名を抽出し、技能 下位児 (以下、下位児と略す) のサンプルとした。 これらの下位児は、下位教材を適切に学習し習得 していったのかどうか、授業中の学習行動を、ビ デオカメラを用いて記録・撮影した。その際、 ALT-PE 観察法注1）を適用し、記録・分析した。

開脚跳びの習得に関する下位教材は、特に、腕 を支点とした体重移動の感覚を習得するために必 要な運動として、「馬跳び、うさぎ跳び、開脚座支 持跳び出し、開脚座腕支持移動、跳び箱・簡易跳 び箱」を対象とし、各々の成功基準を定めた。成 功基準については担当教諭と相談のうえ決定した (表4)。カウント方法については、表4にしたがっ て算出した頻度を基に、成功回数/試行回数=成 功率とした。なお、表4の下位教材はすべて、腕 
表 2. 技術的課題及び下位教材とつまずきに対応した具体的な指導言葉の例

\begin{tabular}{|c|c|c|c|}
\hline 技術的課題 & \begin{tabular}{l|} 
運動 \\
局面
\end{tabular} & 教材と予測されるつまずき & 言葉かけの例 \\
\hline \multirow{2}{*}{$\begin{array}{l}\text { 助走一予備踏 } \\
\text { み切り一踏み } \\
\text { 切りの連続性 }\end{array}$} & \multirow{2}{*}{ (1) (2) } & ウルトラマン跳び○体が丸まり安定した着地ができない。 & $\begin{array}{l}\text { 「ウルトラマンみたいにシュワーッチ」「遠くに } \\
\text { 手だよ」 }\end{array}$ \\
\hline & & $\begin{array}{l}\text { 馬跳び・簡易跳び箱○手のひらがしつかりついてい } \\
\text { ない○体重移動が不十分○片足踏み切り着地になる }\end{array}$ & $\begin{array}{l}\text { 「お馬さんの背中に手のひらがしっかりつい } \\
\text { ているかな」 }\end{array}$ \\
\hline \multirow{3}{*}{$\begin{array}{l}\text { 前方への体の } \\
\text { 投げ出し }\end{array}$} & \multirow{3}{*}{ (3) (4) } & ウルトラマン跳び○体が丸まり安定した着地ができない。 & $\begin{array}{l}\text { 「ウルトラマンみたいにシュワーッチ」「遠くに } \\
\text { 手だよ」 }\end{array}$ \\
\hline & & $\begin{array}{l}\text { jさざ跳び○体の投げ出しが見られない○順次性が } \\
\text { ない }\end{array}$ & $\begin{array}{l}\text { 「ウサギさんの耳はどこにいった?」「遠くに } \\
\text { ピョーンだよ」「足一手一足でつくんたよ」 }\end{array}$ \\
\hline & & $\begin{array}{l}\text { 馬跳び.簡易跳び箱○手のひらがしっかりついてい } \\
\text { ない○体重移動が不十分○片足踏み切りになる }\end{array}$ & $\begin{array}{l}\text { 「お馬さんの背中に手のひらがしっかりつい } \\
\text { ているかな」 }\end{array}$ \\
\hline \multirow{3}{*}{$\begin{array}{l}\text { 足一手一足の } \\
\text { 順 次 性 }\end{array}$} & \multirow{3}{*}{ (3) (4) } & $\begin{array}{l}\text { うさぎ跳び○体の投げ出しが見られない○順次性が } \\
\text { ない }\end{array}$ & $\begin{array}{l}\text { 「ウサギさんの耳はどこにいった?」「遠くに } \\
\text { ピョーンだよ」「足一手一足でつくんだよ」 }\end{array}$ \\
\hline & & $\begin{array}{l}\text { 馬跳び・簡易跳び箱○手のひらがしっかりついてい } \\
\text { ない○体重移動が不十分○片足踏み切り着地になる } \\
\end{array}$ & $\begin{array}{l}\text { 「お馬さんの背中に手のひらがしっかりつい } \\
\text { ているかな」 }\end{array}$ \\
\hline & & $\begin{array}{l}\text { 蛙の足打ち○頭が腰より下がらない○逆立ちの体勢が } \\
\text { とれない○マッ見ることができないで顎をひいてしまう }\end{array}$ & 「何回できるかな」「手を見るんだよ」 \\
\hline \multirow{7}{*}{$\begin{array}{l}\text { 脚を支点とした } \\
\text { 体 重 移 動 }\end{array}$} & \multirow{7}{*}{ (5) 6) } & $\begin{array}{l}\text { 動物 (犬·熊・トカゲ) 歩き、走り○頭より腰が上がらない } \\
\text { バランズ悪くてつまずく○手のひら全体で支えてい } \\
\text { ない○目線が真下で背中が丸まっている○膝を伸ばし } \\
\text { て腰を高く上げることができない }\end{array}$ & $\begin{array}{l}\text { 「両手広げてパーだよ」「膝が1本の棒になる } \\
\text { よ」「前の人のお尻を見るよ」 }\end{array}$ \\
\hline & & 開脚座支持跳び出し ○体を前傾にし遠くに着手できない & 「ここの線を跳び越すよ」 \\
\hline & & $\begin{array}{l}\text { 連結跳び箱での腕支持移動の腕に体重がの } \\
\text { りきらない }\end{array}$ & $\begin{array}{l}\text { 「腕にグーっと体重をのせて」「できるだけ少 } \\
\text { ない数でいこう」 }\end{array}$ \\
\hline & & \begin{tabular}{|l|} 
馬跳び·簡易跳び箱○手のひらがしっかりついていない・ \\
体重移動が不十分○片足踏み切り着地になる \\
\end{tabular} & $\begin{array}{l}\text { 「お馬さんの背中に手のひらがしっかりつい } \\
\text { ているかな」 }\end{array}$ \\
\hline & & 手押し車○腕で体重を支えられないの体が反ってしまう & 「手のひらはパーだよ」「お腹をキュッと締めて」 \\
\hline & & アザラシの腕に体重がのりきらない & 「腕が1本になっているかな」 \\
\hline & & うさぎ跳び○体の投げ出しが見られない 順次性がない & $\begin{array}{l}\text { 「ウサギさんの耳はどこにいった?」「遠くにピョ } \\
\text { 一ンだよ」「足一手一足でつくんだよ」 }\end{array}$ \\
\hline $\begin{array}{l}\text { 突き放し（体の } \\
\text { 切り返し)の技術 }\end{array}$ & (6) (7) & うさぎ跳び○体の投げ出しが見られない 順次性がない & $\begin{array}{l}\text { 「ウサギさんの耳はどこにいった?」「遠くにピョ } \\
\text { ーンだよ」「足一手一足でつくんだよ」 }\end{array}$ \\
\hline \multirow{3}{*}{$\begin{array}{l}\text { 両足で安全に } \\
\text { 着 }\end{array}$} & \multirow{3}{*}{ (6) (7) } & $\begin{array}{l}\text { 跳びおりっこ怖くて跳び出せない } \\
\text { ない }\end{array}$ & $\begin{array}{l}\text { 「両手を床に着けて跳びおりてごらん」「マット } \\
\text { に手をつけるようにおりてみよう」着地したら } \\
\text { ポーズを決めるよ」「スーパーマンみたいに } \\
\text { ジャンプ」 }\end{array}$ \\
\hline & & $\begin{array}{l}\text { 開脚座支持跳び出し(またぎ越しおり)○体を前傾にし遠く } \\
\text { に着手ができない }\end{array}$ & 「ここの線を跳び越すよ」 \\
\hline & & $\begin{array}{l}\text { 馬跳び・簡易跳び箱○手のひらがしっかりついていない○ } \\
\text { 体重移動が不十分○着地が両足でできない。 } \\
\end{array}$ & $\begin{array}{l}\text { 「お馬さんの背中に手のひらがしっかりついて } \\
\text { いるかな」「最後、両足がくつつくかなあ」 }\end{array}$ \\
\hline
\end{tabular}

* (1) （6)の各連動局面 (1)助走 (2)予備踏み切り (3)踏み切り (4)第一空中局面 (5)着手 (6)第二空中局面 (7)着地

表 3. 単元前後による技能評価

\begin{tabular}{|c|c|c|c|c|c|c|}
\hline & \multicolumn{2}{|c|}{ A単元 $(n=28)$} & \multicolumn{2}{|c|}{ B単元 $(n=32)$} & \multicolumn{2}{|c|}{ C単元 $(n=74)$} \\
\hline & 単元前 & 単元後 & 単元前 & 単元後 & 単元前 & 単元後 \\
\hline & \multicolumn{2}{|c|}{ 人数 $(\%)$} & \multicolumn{2}{|c|}{ 人数 $(\%)$} & \multicolumn{2}{|c|}{ 人数 $(\%)$} \\
\hline 跳べる & $24(85.7)$ & $28(100.0)$ & $28(87.5)$ & $32(100.0)$ & $65(87.8)$ & $65(87.8)$ \\
\hline 跳べない & $4(14.3)$ & $0(0.0)$ & $4(12.5)$ & $0(0.0)$ & $9(12.2)$ & $9(12.2)$ \\
\hline
\end{tabular}


表 4.「腕を支点とした体重移動」感覚の修得をねらいとした下位教材の成功基準

\begin{tabular}{|c|l|}
\hline 腕を支点とした体重移動の下位教材 & \multicolumn{1}{c|}{ 下 位 教 材 } \\
\hline 馬跳び & $\begin{array}{c}\text { 助走した状態、もしくはその場跳躍の状態から両足で踏切、両手で着手が } \\
\text { でき、馬を跳びした越し後両足で着地するとができ。 }\end{array}$ \\
\hline うさぎ跳び & $\begin{array}{l}\text { 手一足一手の順次性がある。着手後に状態が起きていて、体の切り返し } \\
\text { が見られる。 }\end{array}$ \\
\hline 開脚座支持跳び出し & 着手位置より前に肩が出て、手の押しで跳び出すことができる。 \\
\hline 連結跳び箱での開脚座腕支持移動 & $\begin{array}{l}\text { 着手した位置より肩が出て、体が前傾した状態で、同時に両手を着手した } \\
\text { 状態で前進するとができる。 }\end{array}$ \\
\hline 跳び箱·簡易跳び箱 & $\begin{array}{l}\text { 助走した状態、もしくはその場跳躍の状態から両足で踏切、両手で着手が } \\
\text { でき、その後、两足で着地することができる。 }\end{array}$ \\
\hline
\end{tabular}

を支点とした体重移動に関する運動の成功率 (以 下、腕を支点とした体重移動の成功率と略す）と して分析対象とした。

\section{III. 結果と考察}

1.A単元の結果

\section{1）授業場面の時間量}

図 1 は、A 単元における各授業場面の時間的割 合の変化を示している。1時間目のインストラク ション場面が $62.8 \%$ で、先行研究（福ヶ迫 2003） と比べてもその割合は高くなった。逆に運動学習 場面は $20.6 \%$ と低くなった。これは、教師が単元 はじめにおいて、授業の進め方に関する指導を多 く行ったためである。また、その後運動学習場面 は徐々に増加していったものの、単元を通しても 平均 $36.6 \%$ と低く、十分な運動学習時間が確保さ れていたとはいえなかった。

もっとも、インストラクション場面では、準備 や片づけ、さらには、学習の流し方に関する説明 が中心となり、課題の学び方や正しい練習方法に 関する説明や指導はほとんどされていなかった。

\section{2）授業の流れと活用された下位教材}

図2は、A 単元の授業の流れとそこで活用され た下位教材を示している。この単元では、開脚跳 びや台上前転の基礎的感覚づくりに焦点をあて、 易しい運動遊び（下位教材）を楽しく挑戦してい るうちに基礎的な感覚が身につき、結果として開 脚跳びができるようになることが目標とされた。

単元を通して授業前半では、4ヶ所の易しい運 動遊びの場（ステーション）が設定され、音楽の
切れ目に合わせてステーションを次々に移動しな がら、全児童が共通の課題を進めていく方式（又 テーション学習)がとられた。授業後半には「チャ レンジタイム」が設定され、そこでは児童たちが 個々の技能レベルに合わせ自由に開脚跳びや台上 前転の下位教材に挑戦でさるよう学習が進められ た。このようにステーション学習やチャレンジタ イムでは多様な下位教材が採用されたが、それぞ れの時間帯で適用される教材が頻繁に入れ替わる ことになった。また、単元前半にはそれらが児童 によって十分活用されていたとはいえず、利用頻 度が極めて少ないものもみられた。何をどのよう に学ぶのかの手順が十分に指導されなかったとこ ろに問題があったといえる。

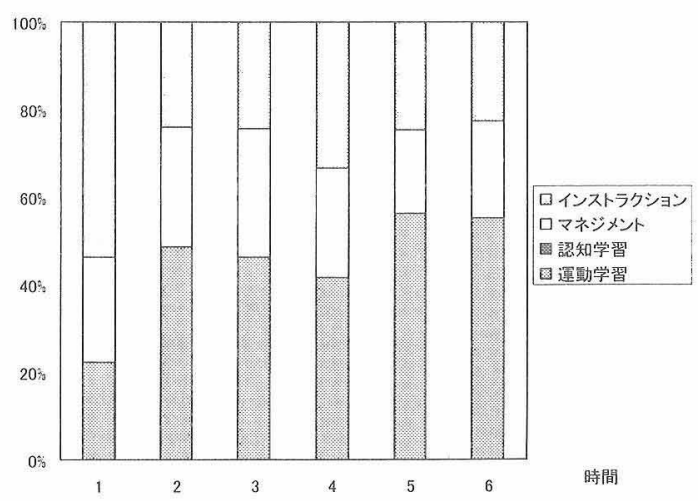

図 1.A 単元における各授業場面の時間的割合 


\begin{tabular}{|c|c|c|c|c|c|c|}
\hline 分 & 1時間目 & 2時間目 & 3時間目 & 4時間目 & 5時間目 & 6時間目 \\
\hline 10 & $\begin{array}{l}\text { Oオリエンテー } \\
\text { ション }\end{array}$ & $\begin{array}{l}\text {-手足走りリ } \\
\text { レー }\end{array}$ & \multicolumn{4}{|c|}{ ○用具の準備 (ステーション学習準備) } \\
\hline 20 & \begin{tabular}{|l|}
$\cdot$ 動物歩き·走り· \\
跳び・アザラシ
\end{tabular} & \multicolumn{3}{|c|}{$\begin{array}{l}\text { Oステーション学習(·馬跳び·ウサギ跳び·カ } \\
\text { エルの足打ち·空中遊泳·連結跳び箱への跳 } \\
\text { びのり·跳び出し) }\end{array}$} & $\begin{array}{l}\text { Oステーション学 } \\
\text { 前転の場も出 } \\
\text { 現) }\end{array}$ & \multirow{3}{*}{$\begin{array}{l}\text { どれだけでき } \\
\text { るかな(開脚 } \\
\text { 跳び・台上前 } \\
\text { 転) }\end{array}$} \\
\hline 30 & $\begin{array}{l}- \text { ウサギ跳びのラ } \\
\text { イン越し } \\
\text { 馬跳び }\end{array}$ & \multicolumn{2}{|c|}{$\begin{array}{l}\text { •運結跳ひ箱での胝を支点と } \\
\text { した前進移動 } \\
\cdot \text {-開脚座からの跳び出し }\end{array}$} & $\begin{array}{l}\text { ·簡易跳び箱で } \\
\text { ·前転がり }\end{array}$ & の開脚跳び & \\
\hline & \begin{tabular}{|l|}
$\cdot$ ・ット \\
$\cdot$ 手足走りリレー
\end{tabular} & \multicolumn{2}{|c|}{ ○チャレンジタイム(開脚跳び) } & \multicolumn{2}{|c|}{$\begin{array}{l}\text { Oチャレンジタイム(開脚跳び、台 } \\
\text { 上前転) }\end{array}$} & \\
\hline 40 & & & & のまとめ & & \\
\hline
\end{tabular}

図2. A 単元の授業の流れと活用された下位教材

表 5. A 児及びB児が各時間に与えられた開脚跳び及び開脚跳びの 下位教材に関わった適切な言語的フィードバックの回数

\begin{tabular}{|c|c|c|c|c|c|c|c|c|}
\hline & & $\begin{array}{l}1 \text { 時間目 } \\
\text { 肯定 矯正 }\end{array}$ & $\begin{array}{l}2 \text { 時間目 } \\
\text { 肯定 矯正 }\end{array}$ & $\begin{array}{l}3 \text { 時間目 } \\
\text { 肯定 镉正 }\end{array}$ & $\begin{array}{l}4 \text { 時間目 } \\
\text { 肯定 稪正 }\end{array}$ & $\begin{array}{l}5 \text { 時間目 } \\
\text { 肯定 矯正 }\end{array}$ & $\begin{array}{l}6 \text { 時間目 } \\
\text { 肯定 矯正 }\end{array}$ & $\begin{array}{c}1 \text { 時間の } \\
\text { 平均 }\end{array}$ \\
\hline \multirow{4}{*}{$\begin{array}{l}\text { A } \\
\text { 単 }\end{array}$} & \multirow{2}{*}{$\begin{array}{c}\text { A览 } \\
\text { (合計) }\end{array}$} & 0 & 2 & 1 & 1 & 2 & & \multirow{2}{*}{5.5} \\
\hline & & 2 & 6 & 6 & 7 & 5 & (7) & \\
\hline & \multirow{2}{*}{$\begin{array}{c}\text { B 児 } \\
\text { (合計) }\end{array}$} & 1 & 1 & 2 & 2 & 1 & $2 \quad 11$ & \multirow{2}{*}{6.3} \\
\hline & & 1 & 6 & 7 & 8 & 3 & (13) & \\
\hline
\end{tabular}

*○は開脚跳び越しができるようになった時間にかけられた適切な言語的フィードバックの回数。

3）下位児に対する教師の指導と下位児の学習

\section{行動}

\section{（1）教師のフィードバック行動}

表 5は、各時間において開脚跳びの下位教材に 関わって、下位児に与えられた適切な言語的 フィードバック（以下、適切なフィードバックと する）の頻度を示したものである。1時間目は授 業の進め方や学び方に関する指導が中心となった ため、下位児との関わりは少なく、A児に対して は 2 回、B览に対しては 1 回のみであった。その 後、単元の進行にともない下位児への適切な フィードバックは増加し、1 時間あたりの適切な フィードバック数の平均は $\mathrm{A}$ 児が 5.5 回、 $\mathrm{B}$ 览が 6.3 回となった。

K教諭は単元前半からかなり積極的に下位児に 関わりをもっていたが、技術的な課題に関する適 切なフィードバックの内容は多様であった。単元 中盤になると、腕を支点とした体重移動に焦点を 合わせた適切なフィードバックが与えられるよう になった。両下位児ともに開脚跳びができるよう になった時間は、教師から適切なフィードバック が一番多く与えられた6時間目であった。そこで、
A 児及びB児の運動学習場面における学習行動や それに対する教師の指導行動について詳しくみる ことにしよう。

\section{（2）下位児の学習行動と教師の指導}

\section{<学習場面の事例 1 >}

A児は腕に体重をのせることが不十分であった ため、開脚座腕支持移動の前進幅は僅かであっ た。また、開脚座支持跳び出しでは、跳び箱にま たぎのった状態で手を使わずにジャンプしていた り、または両足で跳び箱を挟み、跳び出しを行っ ていた。このような A 児に対して教師は 4 時間目 に、「手で押すんだよ。最後に足使っちゃダメ。手 で押しな。(着地では) 足がどこまでいくかな？」 と声をかけ、腕を支点とした体重移動の感覚を意 識させていた。この課題が何とかできるようにな ると、より積極的に体重移動を行わせるために、 着地位置に注意を向けさせ、着地後に「あ！（着 地位置は）黄色の線までいった。次は緑色（の着 地位置まで）までいきたいネ。といって、具体的 な課題を与えようとしていた。さらに、着地位置 から遠く離れたところに目玉の絵 (教具)を置き、 
「目玉を見て。目玉見ながら遠くまで跳び出せ！」と いって、体の切り返しを意識させようとしていた。

\section{〈腕支持感覚を企画する教材の学習成功率〉}

以下では、腕を支点とした体重移動に関する各 下位教材の頻度および、それら学習の成功率につ いてみることにする。

表6は、腕を支点とした体重移動に関する各下 位教材の頻度および割合を示している。A児は馬 跳びやうさぎ跳びに比べ、開脚座支持移動や簡易 跳び箱に多く取り組んでいる。またその一方で、 跳び箱の活用は6 時間目の 3 回のみである。馬跳 びやうさぎ跳びは、予め回数が指定されていたた め頻度が少なくなったが、開脚座支持移動や簡易 跳び箱については、一定の時間内に自由に取り組 み、また、場所も多く設定されていたことにより、 その頻度が多くなったと考えられる。されに、簡 易跳び箱を十分に跳ぶことができていなかったこ ともあり、跳び箱の活用が6時間目までなかった と考えられる。

腕を支点とした体重移動の割合では、3 時間目 $23 \%$ であった成功率が、以降26\%、35\%、43\%と 徐々に増加しており、授業の進行に伴い腕を支点 とした体重移動の感覚が習得されていることがわ かる。これは、単元前半において不適切な方法で 練習を行っていたA児に対し、4 時間目以降教師 の直接的な個別指導により、腕を支点とした体重 移動に関する下位教材の学習を丁寧に進めていく ことに加え、正しい方法で練習が行えるように なったことによるものである。

\section{$<$ 学習場面の事例 $2>$}

$B$ 児は、開脚座支持跳び出しにおいて、体を前 傾させて腕に体重をのせきることができなかっ た。教師は単元中盤より、腕に体重をのせ手で しっかり跳び箱を押すことを指導するようになっ たが、B児は十分な跳び出しには至らなかった。 しかし、5 時間目から教師は、簡易跳び箱（ビー ルビンケース）を活用した指導を行うようにな り、それが有効に機能した。B坚は腕を支点とし た体重移動が習得され、さらには、簡易跳び箱を 跳ぶことができるようになった。その後教師は、 踏切位置を遠くし「体の投げ出し」を意識させた
り、着地時に足を閉じるなどの新しい課題を与え ていった。B児は単元の最後時間では、跳び箱 (3 段）でも開脚跳びができるようになった。

\section{<腕支持感覚を企画する教材の学習成功率＞}

B児の腕を支点とした体重移動に関する各下位 教材の頻度および割合（表7）をみてみると、A児 同様、馬跳びやうさぎ跳びに比べ、開脚座支持移 動や簡易跳び箱に多く取り組んでいる。特に、簡 易跳び箱では、 $5 \cdot 6$ 時間目にかけその頻度が倍増

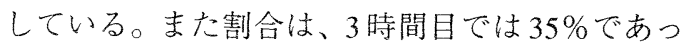
た成功率が、4時間目には一端 $25 \%$ と減少するも のの、5 時間目以降再び $34 \% 、 47 \%$ と増加傾向を 示した。

B児はできてもできなくても仲間と同じ課題に 挑戦し、自分のレベルに合わない場で練習を行う ことが多く、4 時間目はそれが顕著であった。そ のため4時間目に成功率が減少した。しかし、教 師の関わりによって技能レベルに適した場での練 習を行うようになり教材が絞られ、特定の下位教 材の頻度さらには成功率が向上した。このよう に、児童の技能レベルに適した場の提示や段階的 な指導によって、B児はかなりの進歩を示し、技 能習得につながったわけである。

\section{B単元の結果}

\section{1) 授業場面の時間量}

図3は、B 単元における授業場面の時間的割合 を示している。単元が進むにしたがいインストラ クション場面は減少し、運動学習場面は増加し た。潤沢な運動学習場面が確保され、授業は極め て順調に進行したようにみえる。一方で、認知学 習場面はまったく出現しなかったが、それは、授 業が一斉指導で展開されたことに加えて、教師が 多くの運動学習時間を確保するために、学習ノー トへの記入を授業時間外で行うように指導したた めである。

もっとも、運動学習場面は理想的に増加して いったが、単元はじめのインストラクション場面 では、学習の流し方に関する指導が中心となり、 課題の学び方や正しい練習方法に関する指導は十 分にされていなかったことは否めない。 
表 6.A児の腕を支点とした体重移動に関する 各下位教材の頻度および割合

\begin{tabular}{|c|c|c|c|c|c|}
\hline A児 & 時間 & 3 & 4 & 5 & 6 \\
\hline \multirow{4}{*}{ 馬 跳 び } & 成功 & 1 & 2 & 3 & 0 \\
\hline & 失敗 & 3 & 3 & 1 & 0 \\
\hline & 回数 & 4 & 5 & 4 & 0 \\
\hline & $\%$ & 25 & 40 & 75 & - \\
\hline \multirow{4}{*}{ うさぎ跳び } & 成功 & 4 & 4 & 0 & 0 \\
\hline & 失敗 & 2 & 2 & 0 & 0 \\
\hline & 回数 & 6 & 6 & 0 & 0 \\
\hline & $\%$ & 67 & 67 & - & - \\
\hline \multirow{4}{*}{$\begin{array}{l}\text { 開脚座支持 } \\
\text { 跳び出 し }\end{array}$} & 成功 & & 0 & 1 & 2 \\
\hline & 失敗 & 4 & 7 & 4 & 1 \\
\hline & 回数 & 4 & 7 & 5 & 3 \\
\hline & $\%$ & 0 & 0 & 20 & 67 \\
\hline \multirow{4}{*}{$\begin{array}{l}\text { 開脚座支持 } \\
\text { 移動 }\end{array}$} & 成功 & 1 & 3 & 8 & 4 \\
\hline & 失敗 & 10 & 7 & 2 & 0 \\
\hline & 回数 & 11 & 10 & 10 & 4 \\
\hline & $\%$ & 9 & 30 & 80 & 100 \\
\hline \multirow{4}{*}{ 跳 び 箱 } & 成功 & 0 & 0 & 0 & 0 \\
\hline & 失敗 & 0 & 0 & 0 & 3 \\
\hline & 回数 & 0 & 0 & 0 & 3 \\
\hline & $\%$ & - & - & - & 0 \\
\hline \multirow{4}{*}{ 簡易跳び箱 } & 成功 & 1 & 0 & 9 & 14 \\
\hline & 失敗 & 4 & 7 & 32 & 23 \\
\hline & 回数 & 5 & 7 & 41 & 37 \\
\hline & $\%$ & 20 & 0 & 22 & 38 \\
\hline 全体 & $\%$ & 23 & 26 & 35 & 43 \\
\hline
\end{tabular}

*「一」はその時間に挑戦しなかったことを表す。

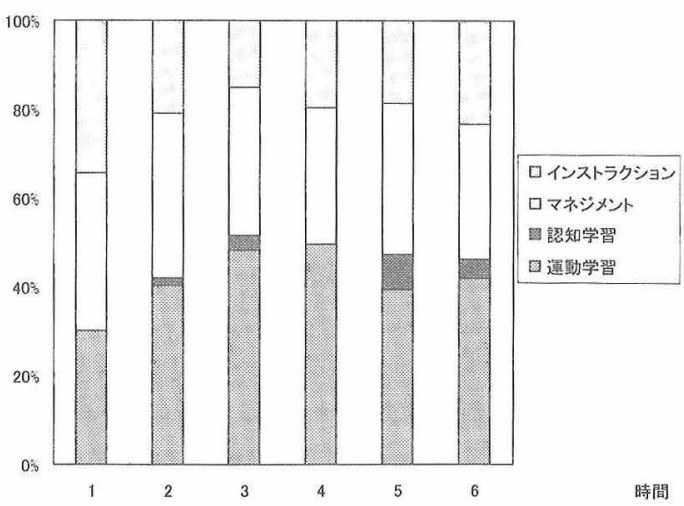

図 3.B単元における各授業場面の時間的割合

\section{2）授業の流れと活用された下位教材}

図4は、B 単元の授業の流れとそこで活用され た下位教材を示している。この単元では、跳び箱 運動につながる基礎的な運動感覚や動きを習得さ
表 7.B児の腕を支点とした体重移動に関する 各下位教材の頻度および割合

\begin{tabular}{|c|c|c|c|c|c|}
\hline B 児 & 時間 & 3 & 4 & 5 & 6 \\
\hline \multirow{4}{*}{ 馬 跳 び } & 成功 & 1 & 1 & 0 & 0 \\
\hline & 失敗 & 4 & 5 & 1 & 0 \\
\hline & 回数 & 5 & 6 & 1 & 0 \\
\hline & $\%$ & 20 & 17 & 0 & - \\
\hline \multirow{4}{*}{ うさぎ跳び } & 成功 & 3 & 2 & 0 & 0 \\
\hline & 失敗 & 2 & 4 & 0 & 0 \\
\hline & 回数 & 5 & 6 & 0 & 0 \\
\hline & $\%$ & 60 & 33 & - & - \\
\hline \multirow{4}{*}{$\begin{array}{l}\text { 開脚座支持 } \\
\text { 跳び出 L }\end{array}$} & 成功 & 1 & 0 & 2 & 1 \\
\hline & 失敗 & 5 & 5 & 4 & 5 \\
\hline & 回数 & 6 & 5 & 6 & 6 \\
\hline & $\%$ & 17 & 0 & 33 & 17 \\
\hline \multirow{4}{*}{$\begin{array}{l}\text { 開脚座支持 } \\
\text { 移動 }\end{array}$} & 成功 & 5 & 5 & 6 & 2 \\
\hline & 失敗 & 6 & 3 & 2 & 2 \\
\hline & 回数 & 11 & 8 & 8 & 4 \\
\hline & $\%$ & 45 & 63 & 75 & 50 \\
\hline \multirow{4}{*}{ 跳 び 箱 } & 成功 & 0 & 0 & 0 & 7 \\
\hline & 失敗 & 0 & 0 & 0 & 6 \\
\hline & 回数 & 0 & 0 & 0 & 13 \\
\hline & $\%$ & - & - & - & 54 \\
\hline \multirow{4}{*}{ 簡易跳び箱 } & 成功 & 1 & 0 & 7 & 15 \\
\hline & 失敗 & 3 & 7 & 22 & 15 \\
\hline & 回数 & 4 & 7 & 29 & 30 \\
\hline & $\%$ & 25 & 0 & 24 & 50 \\
\hline 全 体 & $\%$ & 35 & 25 & 34 & 47 \\
\hline
\end{tabular}

*「一」はその時間に挑戦しなかったことを表す。

せ、開脚跳びが 100\%できるようになることを目 標とした。そこで、単元を通して授業の前半部分 では基礎的感覚づくりに焦点をあて、多くの下位 教材を提供したが、授業の後半では主教材を開脚 跳び1つに絞って、挑戦的に学習できるように計 画した。W教諭は、計画段階で大部分の児童は開 脚跳び越しができていると判断したため、単元前 半には一律に高い跳び箱（4段）を使用したので あるが、下位児にとっては相当困難な課題とな り、腕を支点とした体重移動の習得が不十分なま ま単元が進行することになった。単元中盤になっ てW教諭は、技能レベルの低い子には4段の跳び 箱は難しすぎることに気づき、より易しい下位教 材や低い跳び箱を活用した指導を行った。 
南島：教材活用の仕方や指導行動が学習成果に及ほす影響について

\begin{tabular}{|c|c|c|c|c|c|c|}
\hline 分 & 1時間目 & 2時間目 & 3時間目 & 4時間目 & 5時間目 & 6時間目 \\
\hline 10 & $\begin{array}{l}\text { Oオリエンデ- } \\
\text { ション }\end{array}$ & \multicolumn{5}{|c|}{ ○準備運動 (蛙倒立·蛙の足打ち·馬跳び) } \\
\hline 20 & $\begin{array}{l}\text { O感覚づくり運動 } \\
\text { ·腕支持遊び(・ } \\
\text { 跳びのり、跳び } \\
\text { 出し、前進) }\end{array}$ & \multicolumn{2}{|c|}{$\begin{array}{l}\text { Oステーション学習 } \\
(\text { (•ウサギ跳び·跳び箱や簡易 } \\
\text { 跳び箱での腕支持遊び·壁倒 } \\
\text { 立 })\end{array}$} & $\begin{array}{l}\text { Oステー } \\
(\text { •ウサギ跳び・ } \\
\text { 簡易跳び箱·跳 } \\
\text { び箱·壁倒立・ } \\
\text { 台上前転) }\end{array}$ & $\begin{array}{l}(\cdot \text { ・ウザ跳び・ } \\
\text { 簡易跳び箱や } \\
\text { 丸イスでの開脚 } \\
\text { 跳び })\end{array}$ & $\begin{array}{l}\text { 自分のレベル } \\
\text { に合った場所 } \\
\text { で練習 }\end{array}$ \\
\hline 30 & $\begin{array}{l}\text { ·手押し車 } \\
\text { ·壁倒立 }\end{array}$ & $\begin{array}{l}\cdot \text { 開脚座支持 } \\
\text { 跳び出し }\end{array}$ & $\begin{array}{l}\cdot \text { 連結跳び箱 } \\
\text { への跳びのり }\end{array}$ & \multirow{2}{*}{\multicolumn{2}{|c|}{$\begin{array}{l}\text { 3段もしくは4段の跳び箱で開脚 } \\
\text { 跳び }\end{array}$}} & $\begin{array}{l}\text { Oまとめ } \\
\text { ·発表会 }\end{array}$ \\
\hline 40 & . 馬跳び & \multicolumn{2}{|c|}{ :4段での開脚跳び } & & & \\
\hline 45 & & & & & & \\
\hline
\end{tabular}

図 4.B単元の授業の流れと活用された下位教材

表 8.C児及びD児が各時間に与えられた開脚跳び及び開脚跳びの 下位教材に関わった適切な言語的フィードバックの回数

\begin{tabular}{|c|c|c|c|c|c|c|c|c|c|c|c|c|c|c|}
\hline & & & 間目 & $\begin{array}{l}2 \text { 時 } \\
\text { 肯定 }\end{array}$ & 間目 & $\begin{array}{l}3 \text { 時間目 } \\
\text { 肯定 矯 }\end{array}$ & & $\begin{array}{l}4 \text { 時間 } \\
\text { 肯定 知 }\end{array}$ & & $\begin{array}{l}5 \text { 時 } \\
\text { 肯定 }\end{array}$ & 間目 & $\begin{array}{l}6 \text { 時展 } \\
\text { 肯定 }\end{array}$ & $\begin{array}{l}\text { 間目 } \\
\text { 矯正 }\end{array}$ & $\begin{array}{c}1 \text { 時間の } \\
\text { 平均 }\end{array}$ \\
\hline \multirow{4}{*}{$\begin{array}{l}\text { B } \\
\text { 芫 }\end{array}$} & \multirow{2}{*}{$\begin{array}{c}\text { C 睍 } \\
\text { (合計) }\end{array}$} & 0 & 0 & 0 & 0 & 3 & & 0 & 1 & & 0 & & 0 & \multirow{2}{*}{5.5} \\
\hline & & \multicolumn{2}{|c|}{0} & \multicolumn{2}{|c|}{0} & (7) & \multicolumn{3}{|c|}{1} & \multicolumn{2}{|c|}{1} & \multicolumn{2}{|c|}{1} & \\
\hline & \multirow{2}{*}{$\begin{array}{c}\text { D児 } \\
\text { (合計) }\end{array}$} & 0 & & 0 & 0 & 13 & & 0 & 0 & & 7 & & & \multirow{2}{*}{6.3} \\
\hline & & \multicolumn{2}{|c|}{0} & \multicolumn{2}{|c|}{0} & 4 & \multicolumn{3}{|c|}{0} & \multicolumn{2}{|c|}{8} & \multicolumn{2}{|c|}{ (22) } & \\
\hline
\end{tabular}

*○は開脚跳び越しができるようになった時間にかけられた適切な言語的フィードバックの回数。

3）下位児童に対する教師の指導と下位児童の学 習行動

\section{（1）教師のフィードバック行動}

表 8 は、各時間において開脚跳び及びその下位 教材に関わって下位児に与えられた適切なフィー ドバックの頻度を示している。1 時間目は個別の 関わりはまったくみられなかったが、単元中盤に なると両下位児童とも個別の関わりが現れた。C 児に対しては 3 時間目に、D児には $5 \sim 6$ 時間目 に数多く関わっている。

\section{（2）下位児の学習行動と教師の指導}

\section{<学習場面の事例 $3>$}

C 児は腕を支点とした体重移動が十分ではな く、前進幅が僅かであった。跳び箱に着手しても その場にまたぎのってしまい、また着手位置も跳 び箱の半分よりも手前のところであった。このよ うなつまずきをもったC児に対し、教師が関わり はじめたのは3 時間目からであり、その関わり方 は体を補助しながら簡易跳び箱を越させるもので あった。C児は補助を中心とした指導によって、 腕を支点とした体重移動の感覚が次第に習得され
ていき、その結果、3時間目には跳び箱（3段）で 開脚跳びができるようになった。以降の時間にお いても積極的に課題に挑戦し、6時間目には 4 段 の跳び箱を達成して喜ぶ姿もみられた。

\section{〈腕支持感覚を企画する教材の学習成功率＞}

表 9 は、C児の腕を支点とした体重移動に関す る各下位教材の頻度および割合を示している。単 元前半では、開脚座支持跳び出しや開脚座支持移 動の頻度が他の下位教材と比べ高いが、一方で馬 跳びやうさぎ跳び、跳び箱は少ない頻度のうえ失 敗を繰り返している。単元中盤になると、跳び箱 や簡易跳び箱の活用が中心となり頻度が増加して いる。その割合をみると、2 時間目までは $30 \%$ 以 下であった成功率が、3時間目から $45 \%$ へ上が り、以降64\%、63\%となり、6時間目には $70 \%$ に なった。

これは、多くの児童に合わせ一律の高さの跳び 箱を使用していたため、C児には困難な課題と なったと考えられる。しかし単元中盤から、教師 の補助を中心とした指導により成功率が増加した のである。 
表 9.A児の腕を支点とした体重移動に関する 各下位教材の頻度および割合

\begin{tabular}{|c|c|c|c|c|c|c|c|}
\hline C 児 & $\begin{array}{l}\text { 時間 } \\
\end{array}$ & 1 & 2 & 3 & 4 & 5 & 6 \\
\hline \multirow{4}{*}{ 馬 跳 び } & 成功 & 1 & 2 & 2 & 3 & 3 & 0 \\
\hline & 失敗 & 3 & 3 & 0 & 0 & 0 & 0 \\
\hline & 回数 & 4 & 5 & 2 & 3 & 3 & 0 \\
\hline & $\%$ & 25 & 40 & 100 & 100 & 100 & - \\
\hline \multirow{4}{*}{ うさぎ跳び } & 成功 & 1 & 1 & 2 & 1 & 2 & 0 \\
\hline & 失敗 & 4 & 2 & 0 & 0 & 0 & 0 \\
\hline & 回数 & 5 & 3 & 2 & 1 & 2 & 0 \\
\hline & $\%$ & 20 & 33 & 100 & 100 & 100 & - \\
\hline \multirow{4}{*}{$\begin{array}{l}\text { 開脚座支持 } \\
\text { 跳び出 }\end{array}$} & 成功 & 1 & 2 & 5 & 0 & 0 & 0 \\
\hline & 失敗 & 11 & 7 & 4 & 0 & 0 & 0 \\
\hline & 回数 & 12 & 9 & 9 & 0 & 0 & 0 \\
\hline & $\%$ & 8 & 22 & 56 & - & - & - \\
\hline \multirow{4}{*}{$\begin{array}{l}\text { 開脚座支持 } \\
\text { 移 }\end{array}$} & 成功 & 4 & 3 & 5 & 0 & 0 & 0 \\
\hline & 失敗 & 10 & 6 & 3 & 0 & 0 & 0 \\
\hline & 回数 & 14 & 9 & 8 & 0 & 0 & 0 \\
\hline & $\%$ & 29 & 33 & 63 & - & - & - \\
\hline \multirow{4}{*}{ 跳 び 箱 } & 成功 & 0 & 0 & 5 & 14 & 8 & 16 \\
\hline & 失敗 & 4 & 6 & 16 & 6 & 5 & 7 \\
\hline & 回数 & 4 & 6 & 21 & 20 & 13 & 23 \\
\hline & $\%$ & 0 & 0 & 24 & 70 & 62 & 70 \\
\hline \multirow{4}{*}{ 簡易跳び箱 } & 成功 & 0 & 0 & 0 & 13 & 16 & 0 \\
\hline & 失敗 & 0 & 0 & 0 & 11 & 11 & 0 \\
\hline & 回数 & 0 & 0 & 0 & 24 & 27 & 0 \\
\hline & $\%$ & - & - & - & 54 & 59 & - \\
\hline 全 体 & $\%$ & 18 & 25 & 45 & 65 & 64 & 70 \\
\hline
\end{tabular}

＊「一」はその時間に挑戦しなかったことを表す。

\section{<学習場面の事例 4 >}

$\mathrm{D}$ 児は、開脚座支持跳び出しでは体の前傾が弱 く、腕へ体重をのせることが十分ではなかった。 また、3段の跳び箱に挑戦するが、やはり腕に体 重をのせることが十分できず跳び箱にまたぎのっ ていた。D児に対して教師が関わりはじめるのは 4 時間目からであった。教師は「1回ここでちょっ と補助をやらせて。」言って児童の体を補助し、 跳び越す感覚をつかませようとしていた。5, 6 時 間目には一層積極的に関わるようになり、D児の 技能レベルに合わせた課題（丸イスを連結した長 さのある物）の選定を行った。教師は、それが跳 べないことを確認した後、D児に合わせて、長さ の短い簡易跳び箱を活用するようになった。D児 は何度もそれを練習するうちに、腕を支点とした 体重移動や体の切り返しの感覚を身に付け、簡易 跳び箱を跳ぶことができるようになった。そし
表10、D児の腕を支点とした体重移動に関する 各下位教材の頻度および割合

\begin{tabular}{|c|c|c|c|c|c|c|c|}
\hline D児 & 時間 & 1 & 2 & 3 & 4 & 5 & 6 \\
\hline \multirow{4}{*}{ 馬 跳 び } & 成功 & 2 & 3 & 2 & 3 & 3 & 0 \\
\hline & 失敗 & 3 & 2 & 1 & 0 & 0 & 0 \\
\hline & 回数 & 5 & 5 & 3 & 3 & 3 & 0 \\
\hline & $\%$ & 40 & 60 & 67 & 100 & 100 & - \\
\hline \multirow{4}{*}{ うさぎ跳び } & 成功 & 2 & 1 & 0 & 0 & 2 & 0 \\
\hline & 失敗 & 2 & 2 & 2 & 0 & 5 & 0 \\
\hline & 回数 & 4 & 3 & 2 & 0 & 7 & 0 \\
\hline & $\%$ & 50 & 33 & 0 & - & 29 & - \\
\hline \multirow{4}{*}{$\begin{array}{l}\text { 開脚座支持 } \\
\text { 跳 び出 }\end{array}$} & 成功 & 0 & 1 & 0 & 0 & 0 & 0 \\
\hline & 失敗 & 6 & 3 & 5 & 0 & 0 & 0 \\
\hline & 回数 & 6 & 4 & 5 & 0 & 0 & 0 \\
\hline & $\%$ & 0 & 25 & 0 & - & - & - \\
\hline \multirow{4}{*}{$\begin{array}{l}\text { 開脚座支持 } \\
\text { 移 }\end{array}$} & 成功 & 0 & 2 & 2 & 0 & 0 & 0 \\
\hline & 失敗 & 18 & 8 & 13 & 0 & 0 & 0 \\
\hline & 回数 & 18 & 10 & 15 & 0 & 0 & 0 \\
\hline & $\%$ & 0 & 20 & 13 & - & - & - \\
\hline \multirow{4}{*}{ 跳 び 箱 } & 成功 & 0 & 0 & 0 & 0 & 0 & 3 \\
\hline & 失敗 & 5 & 4 & 11 & 0 & 2 & 26 \\
\hline & 回数 & 5 & 4 & 11 & 0 & 2 & 29 \\
\hline & $\%$ & 0 & 0 & 0 & - & 0 & 10 \\
\hline \multirow{4}{*}{ 簡易跳び箱 } & 成功 & 0 & 0 & 1 & 1 & 6 & 15 \\
\hline & 失敗 & 0 & 0 & 12 & 22 & 20 & 8 \\
\hline & 回数 & 0 & 0 & 13 & 23 & 26 & 23 \\
\hline & $\%$ & - & - & 8 & 4 & 23 & 65 \\
\hline 全 体 & $\%$ & 11 & 27 & 10 & 15 & 29 & 35 \\
\hline
\end{tabular}

*「一」はその時間に挑戦しなかったことを表す。

て、6時間目終了間際には、跳び箱 (3段) でも開 脚跳びができるようになった。

\section{<腕支持感覚を企画する教材の学習成功率＞}

D児の腕を支点とした体重移動に関する各下位 教材の頻度および割合（表 10）をみると、C児と 比べ開脚座支持跳び出しや開脚座支持移動、跳び 箱の頻度が少ない。もっとも、馬跳びやうさぎ跳 びに関しては、回数が指定されていたこともあ り、挑戦頻度に大きな違いはみられない。4、5時 間目になり簡易跳び箱の頻度が上昇し、さらに 6 時間目には、跳び箱の頻度も大幅に増加してい る。D児は、1時間目の成功率が $11 \%$ あっったが、 2 時間目には $27 \%$ となり、3、4時間目になると 10 \%、15\%と低い值を示している。ところが、5、6 時間目には $29 \% 、 35 \%$ と上昇傾向を示した。

これは、単元後半からの積極的な教師の関わり 
によって、D罗の技能レベルに適した下位教材 （簡易跳び箱）を提供したことが影響したと推測 される。加えてD巟は、教師の個別指導によって 5 時間目の後半から簡易跳び箱が跳べるようにな り、さらに6 時間目の終盤では跳び箱（3段）も 跳べるようになったのである。

\section{C 単元の結果}

1) 授業場面の時間量

図5 はC単元の各授業場面の時間的割合を示し ている。1時間目のインストラクション場面は $34.5 \%$ と高くなったが、単元の進行につれ減少し ていっだー方で、マネジメント場面の割合は、単 元を通し 30\%を下回ることはなかった。

$$
\text { もっとも、単元はじめのインストラクション場 }
$$

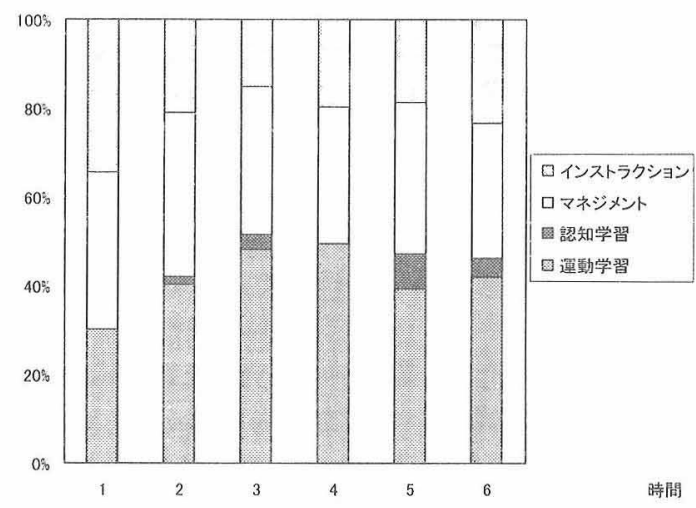

図 5.C 単元における各授業場面の時間的割合
面では、準備や片づけ、学習の流し方に関する指 導が綿密に行われたが、課題の学び方や正しい練 習方法に関する指導はほとんどされていなかっ た。加えて C 単元では、開脚跳びと台上前転の 2 つが主教材として位置づけられ、しかも、台上前 転に関わった多くの下位教材や場を隼備すること が必要だったため、最後まで十分な運動学習場面 の時間量を確保することはできなかった。

\section{2）授業の流れと活用された下位教材}

図6は、C単元の授業の流れとそこで活用され た下位教材を走している。Y教諭は児童が4 年生 であるということから、大きな開脚跳びや大きな 台上前転ができるようになることを目標とした。 そのため、児童が能力に応じて学習できるよう、 多様な下位教材や場が提供された。また、授業前 半には開脚跳びと台上前転の感覚づくりの運動を 「基礎学習」として位置づけ、授業後半の「発展学 習」では、技能の習得段階に応じて学習課題や場 が選択できる「課題選択学習」が採用された。そ の際、授業前半に用いられた開脚跳びの下位教材 は、児童によっては単元中盤から十分に活用され なくなってしまった。これは、数人の下位児を除い て開脚跳び越しができるようになったからである。

3）下位児童に対する教師の指導と下位児童の学 習行動

(1) 教師のフィードバック行動

表11は、教師が、各時間において開脚跳び及び

\begin{tabular}{|c|c|c|c|c|c|c|}
\hline 分 & 1時間目 & 2時間目 & ３時間目 & 4時間目 & 5時間目 & 6時間目 \\
\hline 10 & $\begin{array}{l}\text { Oオリエンテー } \\
\text { ション } \\
\text { •授業のねらい } \\
\text { 進行方法の理解 }\end{array}$ & \multicolumn{2}{|c|}{$\begin{array}{l}\text { ○健康確認・用具や場の確 } \\
\text { 認·学習内容の確認O準備 } \\
\text { 運動 } \mathrm{O} \text { 基礎学習 (共通譯題) }\end{array}$} & \multicolumn{3}{|c|}{$\begin{array}{l}\text { O健康確認·用具や場の確認·学習内容の確認 } \\
\text { O準備運動(ゆかがウサザ跳びなど) }\end{array}$} \\
\hline 20 & $\begin{array}{l}\text { ·場の設定の仕 } \\
\text { 方、安全に対す } \\
\text { る注意 }\end{array}$ & $\begin{array}{l}\text {-蛙の足打ち } \\
\text {-ウサギ跳ひ } \\
\text {-簡易跳び籍 }\end{array}$ & $\begin{array}{l}\text { ·譬倒立 } \\
\text { •前転 } \\
\text { このとび越し }\end{array}$ & \multicolumn{3}{|c|}{$\begin{array}{l}\text { ·開脚跳び } \\
\text { ·大きな前転·台上前転 }\end{array}$} \\
\hline & $\begin{array}{l}\text {-準備運動、慣れ } \\
\text { の運動の仕方 }\end{array}$ & -關剖跳び & \multicolumn{4}{|c|}{$\begin{array}{l}\text {-連結跳び箱での跳びのり·連結跳び箱での腕支持移動·開脚 } \\
\text { 支支持跳び出し }\end{array}$} \\
\hline 30 & $\begin{array}{l}\text { "自分のできる技 } \\
\text { を確かめる }\end{array}$ & \multicolumn{2}{|c|}{$\begin{array}{l}\text { O発屒学習1（選択課題） } \\
\text { 台上前転 }\end{array}$} & \multicolumn{3}{|c|}{$\begin{array}{l}\text { O発展学習2（選択課題） } \\
\text { 台上前転 }\end{array}$} \\
\hline 40 & $\begin{array}{l}\text { •グルーピング } \\
\text { (ペアの確認) } \\
\text { •めあての確認 }\end{array}$ & \multicolumn{2}{|c|}{$\begin{array}{l}(\cdot \text { 簡易跳び箱·跳び箱"前 } \\
\text { 転·台上への前回り・大きな } \\
\text { 台上前転) }\end{array}$} & \multicolumn{2}{|c|}{$\begin{array}{l}\text { ·大きな台上前転 } \\
\text { ·集団演技(動きを合わせた前 } \\
\text { 転) }\end{array}$} & ○発表会 \\
\hline 45 & -片付け & \multicolumn{5}{|c|}{ ○学習のまとめ, 後片付け } \\
\hline
\end{tabular}

図 6.C 単元の授業の流れと活用された下位教材 
表 11. E 児及びF児が各時間に与えられた開脚跳び及び開脚跳びの 下位教材に関わった言語的フィードバックの回数

\begin{tabular}{|c|c|c|c|c|c|c|c|c|}
\hline & & $\begin{array}{l}1 \text { 時間目 } \\
\text { 肯定 矯正 }\end{array}$ & $\begin{array}{l}2 \text { 時間目 } \\
\text { 肯定 稪正 }\end{array}$ & $\begin{array}{l}3 \text { 時間目 } \\
\text { 肯定 矯正 }\end{array}$ & $\begin{array}{l}4 \text { 時間目 } \\
\text { 肯定 矯正 }\end{array}$ & $\begin{array}{l}5 \text { 時間目 } \\
\text { 肯定 矯正 }\end{array}$ & $\begin{array}{l}6 \text { 時間目 } \\
\text { 肯定 矯正 }\end{array}$ & $\begin{array}{c}1 \text { 時間の } \\
\text { 平均 }\end{array}$ \\
\hline \multirow{4}{*}{$\begin{array}{l}\text { C } \\
\text { 単 } \\
\text { 兄 }\end{array}$} & \multirow{2}{*}{$\begin{array}{c}\text { E罗 } \\
\text { (合計) }\end{array}$} & & \begin{tabular}{ll|}
0 & 0
\end{tabular} & $\begin{array}{ll}0 & 2\end{array}$ & $\begin{array}{ll}0 & 0\end{array}$ & $\begin{array}{ll}0 & 0\end{array}$ & $0 \quad 0$ & \multirow{2}{*}{0.3} \\
\hline & & 0 & 0 & 2 & 0 & 0 & 0 & \\
\hline & \multirow{2}{*}{$\begin{array}{c}F^{\text {児 }} \\
\text { (合計) }\end{array}$} & 0 & 0 & 0 & 0 & 1 & 0 & \multirow{2}{*}{0.3} \\
\hline & & 0 & 0 & 0 & 0 & 2 & 0 & \\
\hline
\end{tabular}

その下位教材に関わって下位児に与えた適切な フィードバックの頻度を示している。1時間あた りの平均頻度は両下位児とも 0.3 回であり、単元 を通して極めて少なかった。この単元では、多く の児童が台上前転に関心を向けでいたため、下位 巟に対する教師の指導も台上前転に関するものが 多くなった。そのため、適切なフィードバックが 少なくなった原因の 1 つである。もっとも、教師 が児童のつまずきを的確に見抜いていなかったこ とも否めない。

\section{（2）下位児の学習行動と教師の指導}

\section{<学習場面の事例 $5>$}

E児は「課題選択学習」の場面では、台上前転 を選択して学習したので、開脚跳びに関連した学 習の頻度は少なかった。しかし、「基礎学習（予備 的運動)」の場面では開脚跳びにつながる下位教 材が提供されていたので、そこでの学習行動に注 目すると、連結跳び箱への跳びのりの課題では、 軽く走って一度止まってから跳びのっており、ま た、開脚座支持体重移動においては僅かな前進幅 であった。開脚座支持跳び出しでは、跳び箱を滑 り落ちるような状態、もしくは、両足を跳び箱に 挟んだ状態でジャンプしておりていた。もっと も、教師は簡易跳び箱において全員に、“着地時に 両足を閉じること”を強調しており、E児が腕を 支点とした体重移動を意識して跳ぶ姿はみられ ず、また、E児に対して教師が個別に指導するこ ともほとんどなかった。

\section{<腕支持感覚を企画する教材の学習成功率 $>$}

E児の腕を支点とした体重移動に関する各下位 教材の頻度および割合（表 12）をみると、どの下 位教材も学習頻度が少ないことがわかる。唯一跳
び箱の使用が 4 時間目以降 10 回を越しているが、 それも決して高い数值といえるものではなく、さ らに1度も跳べていないこともわかる。さらに3 時間目には31\%だった成功率がこの時間を境に減 少していき、5時間目にはついに $0 \%$ になった。6 時間目には $12 \%$ と若干上昇したが、E児は最後ま で跳び箱が跳び越せないまま単元が終了してし まった。

このような結果に終わった原因として以下の 3 点があげられる。第 1 に、2つの主教材が同等の 重みで設定されていたため開脚跳びに関する下位 教材の学習頻度が少なかった。それにより、腕を 支点とした体重移動の感覚が、十分に習得される 前に次の課題に移ることになった。第2に、自発 的な「課題選択学習」によって進められたため、他 の仲間に追随して「発展学習」に進むことになり、 技能レベルに適さない教材や場を選択していた。 第3に、教師が個別にほとんど関わらなかったこ とである。

\section{<学習場面の事例 $6>$}

F児においても、「課題選択学習」の場面では開 脚跳びも含めて学習したが、やはり腕を支点とし た体重移動の感覚がつかめず、単元中盤まで簡易 跳び箱で失敗を繰り返していた。また、開脚座支 持跳び出しにおいても、腕に体重をのせることが 十分できていなかった。これに対して教師は、下 位教材の意図に則して正しい運動の行い方を指導 するのではなく、「じゃー違う（次の）場でやって みようか」と声をかけて「学習の進め方」につい て指示を与えるだけであった。また、F児が間違っ た方法で練習していても、「OK、OK、う一ん、い いね。」といって、肯定的なフィードバックを与え る場面もあった。 
表12、E児の腕を支点とした体重移動に関する 各下位教材の頻度および割合

\begin{tabular}{|c|c|c|c|c|c|c|c|}
\hline E児 & 時間 & 1 & 2 & 3 & 4 & 5 & 6 \\
\hline \multirow{4}{*}{ 馬 跳 び } & 成功 & 0 & 0 & 0 & 0 & 0 & 0 \\
\hline & 失敗 & 0 & 0 & 0 & 0 & 0 & 0 \\
\hline & 回数 & 0 & 0 & 0 & 0 & 0 & 0 \\
\hline & $\%$ & - & - & - & - & - & - \\
\hline \multirow{4}{*}{ うさざ跳び } & 成功 & 0 & 0 & 0 & 0 & 0 & 0 \\
\hline & 失敗 & 0 & 3 & 2 & 5 & 0 & 0 \\
\hline & 回数 & 0 & 3 & 2 & 5 & 0 & 0 \\
\hline & $\%$ & - & 0 & 0 & 0 & - & - \\
\hline \multirow{4}{*}{$\begin{array}{l}\text { 開脚座支持 } \\
\text { 跳び出し }\end{array}$} & 成功 & 0 & 0 & 0 & 1 & 0 & 0 \\
\hline & 失敗 & 3 & 5 & 4 & 6 & 2 & 0 \\
\hline & 回数 & 3 & 5 & 4 & 7 & 2 & 0 \\
\hline & $\%$ & 0 & 0 & 0 & 14 & 0 & - \\
\hline \multirow{4}{*}{$\begin{array}{l}\text { 開脚座支持 } \\
\text { 移 動 }\end{array}$} & 成功 & 0 & 3 & 4 & 2 & 0 & 0 \\
\hline & 失敗 & 0 & 4 & 3 & 8 & 3 & 0 \\
\hline & 回数 & 0 & 7 & 7 & 10 & 3 & 0 \\
\hline & $\%$ & - & 43 & 57 & 20 & 0 & - \\
\hline \multirow{4}{*}{ 跳び 箱 } & 成功 & 0 & 0 & 0 & 0 & 0 & 0 \\
\hline & 失敗 & 6 & 8 & 7 & 10 & 12 & 14 \\
\hline & 回数 & 6 & 8 & 7 & 10 & 12 & 14 \\
\hline & $\%$ & 0 & 0 & 0 & 0 & 0 & 0 \\
\hline \multirow{4}{*}{ 簡易跳び箱 } & 成功 & 3 & 3 & 4 & 2 & 0 & 2 \\
\hline & 失敗 & 1 & 4 & 2 & 6 & 2 & 1 \\
\hline & 回数 & 4 & 7 & 6 & 8 & 2 & 3 \\
\hline & $\%$ & 75 & 43 & 67 & 25 & 0 & 67 \\
\hline 全 体 & $\%$ & 23 & 20 & 31 & 13 & 0 & 12 \\
\hline
\end{tabular}

*「一」はその時間に挑戦しなかったことを表す。

\section{〈腕支持感覚を企画する教材の学習成功率＞}

F児の腕を支点とした体重移動に関する各下位 教材の頻度および割合（表 13）をみてみると、E 児同様、どの下位教材も学習頻度が少ないことに 加え、跳び箱は 1 度も跳べず、簡易跳び箱におい ても成功数が失敗数を上回ることはほとんどな かった。F児は、1時間目の成功率は13\%であり、 2 時間目も $17 \%$ と低い值を示し、3 時間目にはつ いに0\%となった。4 時間目には、18\%、5 時間目 には23\%と若干増加したものの、6時間目には再 び14\%と減少した。このような結果が現れた原因 として、主教材が2つ設定されていたこと。また 「課題選択学習」によって、的を絞った学習ができ ず、開脚跳びに関する課題への頻度が少なくなっ たことが考えられる。
表13、F児の腕を支点とした体重移動に関する 各下位教材の頻度および割合

\begin{tabular}{|c|c|c|c|c|c|c|c|}
\hline F児 & 時間 & 1 & 2 & 3 & 4 & 5 & 6 \\
\hline \multirow{4}{*}{ 馬 跳 び } & 成功 & 0 & 0 & 0 & 0 & 0 & 0 \\
\hline & 失敗 & 0 & 0 & 0 & 0 & 0 & 0 \\
\hline & 回数 & 0 & 0 & 0 & 0 & 0 & 0 \\
\hline & $\%$ & - & - & - & - & - & - \\
\hline \multirow{4}{*}{ うさざ跳び } & 成功 & 0 & 0 & 0 & 0 & 1 & 1 \\
\hline & 失敗 & 0 & 1 & 3 & 8 & 5 & 3 \\
\hline & 回数 & 0 & 1 & 3 & 8 & 6 & 4 \\
\hline & $\%$ & - & 0 & 0 & 0 & 17 & 25 \\
\hline \multirow{4}{*}{$\begin{array}{l}\text { 開脚座支持 } \\
\text { 跳び出し }\end{array}$} & 成功 & 0 & 0 & 0 & 1 & 0 & 0 \\
\hline & 失敗 & 5 & 6 & 4 & 5 & 3 & 0 \\
\hline & 回数 & 5 & 6 & 4 & 6 & 3 & 0 \\
\hline & $\%$ & 0 & 0 & 0 & 17 & 0 & - \\
\hline \multirow{4}{*}{$\begin{array}{l}\text { 開脚座支持 } \\
\text { 移 }\end{array}$} & 成功 & 0 & 3 & 0 & 5 & 2 & 0 \\
\hline & 失敗 & 0 & 2 & 0 & 4 & 2 & 0 \\
\hline & 回数 & 0 & 5 & 0 & 9 & 4 & 0 \\
\hline & $\%$ & - & 60 & - & 56 & 50 & - \\
\hline \multirow{4}{*}{ 跳び 箱 } & 成功 & 0 & 0 & 0 & 0 & 0 & 0 \\
\hline & 失敗 & 4 & 7 & 5 & 14 & 8 & 7 \\
\hline & 回数 & 4 & 7 & 5 & 14 & 8 & 7 \\
\hline & $\%$ & 0 & 0 & 0 & 0 & 0 & 0 \\
\hline \multirow{4}{*}{ 簡易跳び箱 } & 成功 & 2 & 1 & 0 & 1 & 3 & 2 \\
\hline & 失敗 & 4 & 3 & 2 & 5 & 2 & 8 \\
\hline & 回数 & 6 & 4 & 2 & 6 & 5 & 10 \\
\hline & $\%$ & 33 & 25 & 0 & 17 & 60 & 20 \\
\hline 全 体 & $\%$ & 13 & 17 & 0 & 16 & 23 & 14 \\
\hline
\end{tabular}

*「一」はその時間に挑戦しなかったことを表す。

\section{IV。摘 要}

実際の体育授業場面を想定すると、有効だとさ れる下位教材を適用するだけで開脚跳びができる ようになるわけではなく、教師の実践的指導力が 問われると考えられる。そこで本研究では、開脚 跳びの達成に有効だと考えられている「下位教材 群」や、「つまずきに対応した指導言葉集」を3名 の小学校教師に資料として提供し、それらが教師 の裁量によってどのように計画・実行され、また、 授業中の教師の指導行動としてどのように反映さ れたのか。特に、開脚跳び越しのできない児童を 対象にした教師の指導行動に焦点をあて、分析 · 検討することにした。

本研究では、以下のような結果が得られた。

(1)指導計画の立て方

3 名の教師に共通して、単元前半では、インス 
トラクション場面やマネジメント場面が多くなっ た。特にインストラクション場面では、準備や片 づけ、学習の流し方に関する説明が中心となっ た。しかし、A 単元とB 単元では、単元中盤にお いて授業の流れが確立され始めたが、C 単元で は、マネジメント場面が大きく減少することはな かった。

\section{(2)教材の配置・配列の仕方}

3 名の教師とも、基礎的な感覚づくりに焦点を あてた多様な下位教材が採用された反面、単元を 通して活用され続けることはなかった。特に、A 単元や B 単元では、単元中盤から再度、個別に下 位教材を活用するようになったが、C単元におい ては、提供された下位教材が全児童によって正し く学習されていたとは言えず、児童によっては、 不適切な方法で学習している場面もみられた。さ らに、単元中盤からは開脚跳びにつながる下位教 材は、まったく活用されなくなってしまった。

\section{(3)教師の指導行動}

\section{くフィードバック行動 $>$}

下位児の大部分は、「腕を支点とした体重移動」 や「体の切り返し」に問題をもっていた。なお、A 単元およびB単元においては、その部分に焦点を あてた下位教材の活用や教師による個別指導 (指 導言葉や補助）がなされていたが、C単元におい ては、その部分に焦点をあてた指導や児童のつま ずきに応じた適切なフィードバックは十分にされ ていなかった。

\section{<学び方の指導〉}

どの単元も単元前半では、課題の学び方や正し い練習方法に関する指導はほとんどされていな かった。しかし、A 単元およびB 単元では、単元 中盤から下位児に対し個別に関わる余裕がうまれ ると、個々人の能力に応じて適切な下位教材や課 題を提供したり、あるいは、補助を行うことがで きるようになった。一方C 単元では、児童の自発 的な学習が尊重されたこともあり、教師が下位児 に対する関わり極めて少なく、また、不適切な方 法で学習している場合においても、学び方に関す る適切な指導はされなかった。
3 授業を通し、下位児の開脚跳び越しの技能に ついては、A 単元と B 単元では概ね保障すること ができたが、一方で、C単元の下位児においては、 十分に保障されたとはいえなかった。

以上の点をふまえ、本研究を通して以下のこと が提案できる。

単元前半では、すべての児童に易しい同一の下 位教材を学習させ、その同一の下位教材のなかで 能力に応じて異なった挑戦課題を与える方法が有 効であると考えられる。また、今回行われた $3 つ$ の単元を観察して、6授業時間というのは教師が 余裕をもって指導し、すべての児童に目標技の習 得に必要な基礎的な技能を保障するにはあまりに も短く感じられた。少なくともあと 2 時間あ れば下位児もより確実に技能を習得することがで き、身につけた技能を基に、より豊かに運動を楽 しむことができたのではないかと思われる。

また、つまずきをもつ児童においては、適切な フィードバックを与えることに加え、課題解決の ためのめあてや、個別に下位教材を与え、それを どのように活用するのかといった学び方の指導を 与える必要がある。

早期の段階で、目標技の習得に必要な基礎的な 技能を身に付けさせることは、児童の学習意欲を 高め、より大きな学習成果を生み出すためには大 切なことである。そのためには、類似の運動を含 む下位教材であっても、学び方の指導や正しい練習 の仕方を十分理解させ丁寧に指導する必要がある。

\section{注}

1) ALT-PE (Academic Learning Time in Physical Education）とは、「学習者が体育的内容に有効かつ 成功裡に従事する時間量の割合」(Metzler) と 定義されている。本研究では、高橋（2000）に よって行われた観察法を、ビデオカメラを用い て適用し、12 秒インターバルで観察・記録を 行った。なお本来、体育授業場面を「体育的内 容場面」、「学習従事場面 (認知的学習、運動学 習) 」、「成功裡な運動学習 (運動の ALT)」と区 分して観察・記録するが、本研究では、簡便化 を図るために、運動学習場面に限定し、なおか つ、運動学習のALTを対象に分析を行った。 


\section{引用・参考文献}

藤井喜一（1992） II ．基本の運動の内容と学習指 導. 高橋健夫 ·林 恒明 $\cdot$ 藤井喜一. 大貫耕 一(編著) 基本の運動の授業. 体育科教育 40 (8) : 46-49.

藤井喜一 (1997) どの子でもできる器械運動(5)跳び箱運動その 1 -。体育科教育 45(11):5-8. 上條眞紀夫（1992）ＩI．基本の運動の内容と学習 指導. 高橋健夫 ·林 恒明 $\cdot$ 藤井喜一 . 大貫 耕一（編著）基本の運動の授業. 体育科教育 $40(8): 26-33$

福ヶ迫喜彦・スロト・小松崎敏・米村耕平・高橋

健夫 (2003) 体育授業における「授業の勢い」 に関する検討：小学校体育授業における学習 従事と形成的授業評価との関係を中心に. 体 育学研究 48(3) : 281-297.

岩田＼cjkstart靖（1994）体育授業の教材づくり。高橋健 夫（編著）体育授業を創る。大修館書店：東 京, pp. 26-33.

金子明友（1987）とび箱・平均台運動。大修館書 店：東京, p. 9.

小林 篤（1981）体育授業での教師の手入れ．現 代教育科学 29(9)：19-28.

小久保昇治（1981）みんなが跳び越せる跳び箱の

段階指導。現代教育科学 24(9):39-46.

文部科学省（2005）「中央教育審議会初等中等教 育分科会教育課程部会健やかな体を育む教育 の在り方に関する専門部会体育分野ワーキン ググループ (平成 17 年 9 月 29 日)」 (http:// www.mext.go.jp/shingi/chukyo/chukyo3/gijiroku/ 027/06031603.htm).

文部科学省 (2005a)「中央教育審議会初等教育分 科会教育課程部会健やかな体を育む教育の在 り方に関する専門部会 (平成 17年7月27日)」 これまでの審議の状況一すべての子どもたち が身に付けているべきミニマムとは? 一。 (http://www.mext.go.jp/b_menu/shingi/chukyo/ chukyo0/toushin/05091401.htm).

文部科学省（2006）「中央教育審議会初等中等教 育分科会教育課程部会審議報告書（平成 18 年2月13日)」( http://www.mext.go.jp/b_menu/ shingi/chukyo/chukyo3/siryo/004/06021401.htm).
Metzler, M. (1979) The measurement of academic learning time in physical education. (Doctoral disserration, The Ohio State University) Ann Arbor, MI, University Microfilms No. 8009314. p. 8. 松本格之祐（1995）楽しい運動例と指導ことば集 - (1)器械運動編一。学校体育48(10)：136-156. 松本格之祐（1999）図解「器械運動の技の系統」。 学校体育 52(12)：40-43.

松井貞夫（1983）子どもの発達に即した跳び箱運 動の授業. 体育の科学 33(7): 523-529.

向山洋一（1981）授業の本質と跳び箱運動の本質 一跳び箱運動の跳ばせ方をめぐって一。現代 教育科学 24(9):29-38.

進藤省次郎（1981）跳び箱運動の特徵と技術的指 導の課題. 現代教育科学 29(9): 12-18.

高橋健夫（1987）体育科「追試」実践のここを改 善したい．現代教育科学 30(12)：49-53.

高橋健夫 (1991) 新しい体育の授業研究. 大修館 書店：東京, pp. 33-43.

高橋健夫·岡沢祥訓・中井隆司·芳本 真 (1991a) 体育授業における教師行動に関する研究一教 師行動の構造と児童の授業評価との関係一。 体育学研究 36 (3)：193-208.

高橋健夫（1992）器械運動の授業づくり.大修館 書店：東京.

高橋健夫（1994）体育授業を創る。大修館書店： 東京, pp. 76-80.

高橋健夫（1998）子どもと楽しむ体育の授業(3)これは簡単! 器械運動一。学事出版株式会 社：東京.

高橋健夫 (2000) 子どもが評価する体育授業過程 の特徵: 授業過程の学習行動及び指導行動と 子どもによる授業評価との関係を中心に. 体 育学研究 45(2)：147-162.

高橋健夫（2003）体育授業を観察評価する。高橋 健夫（編著）体育授業を観察評価する。明和 出版: 東京, pp. 36-39.

和田 卓 (1999) 開脚跳びができないイラストで みる恼める子への指導. 学校体育52(9):62-63. 渡辺良夫 (2000) 子どもにやさしい器械運動一技 につながるやさしい運動遊び事例集一。学校 体育 $54(3)$ : 8-13. 